\title{
Téoros
}

Revue de recherche en tourisme

\section{The political Fragility of Tourism in Developing Nations}

\section{Linda K. Richter}

Volume 13, numéro 2, été 1994

Regards sur le tourisme dans les pays en développement

URI : https://id.erudit.org/iderudit/1077757ar

DOI : https://doi.org/10.7202/1077757ar

Aller au sommaire du numéro

Éditeur(s)

Université du Québec à Montréal

ISSN

0712-8657 (imprimé)

1923-2705 (numérique)

Découvrir la revue

Citer cet article

Richter, L. K. (1994). The political Fragility of Tourism in Developing Nations. Téoros, 13(2), 12-15. https://doi.org/10.7202/1077757ar d'utilisation que vous pouvez consulter en ligne.

https://apropos.erudit.org/fr/usagers/politique-dutilisation/ 


\title{
The political Fragility of Tourism in Developing Nations
}

\author{
Linda K. Richter*
}

\section{The Paradoxes of Tourism Development}

There are many paradoxes in the effort to develop tourism in developing nations. There is the promotional paradox: How does one compete in promoting a destination as desirable for leisure when most of its inhabitants live short lives in squalor and disease? There is the allocation paradox: How does a gouvernment that cannot provide basic necessities for its own citizens allocate scarce funds, often in the form of foreign exchange, or provide tax concessions to provide promotional and infrastructure needs for the pleasure of primarily non-citizens? Unlike developed countries most developing nations - India and China are exceptions - derive most of their tourism revenues from international rather than domestic tourists.

There are other paradoxes as well. There is the luxury paradox. In most developing nations, there is almost an inverse ratio between the economic and social condition in the society and the lavishness of the tourism infrastructure. Consider the opulentresorts in the Gambia, the Philippines, and Thailand. Scarcely any of the infrastructure for the resorts benefits the general population aside from those directly employed - usually at the bottom of a labor market that rarely has a career ladder (Wood, 1981: 2-13; Wahnschafft, 1982; 429-451; Harrell-Bond, 1978).

Given these paradoxes, is it any wonder that the most problematical is the security paradox: How does a government - usually with inadequate, underpaid police and military and with often de facto control over much less than the total nation provide a safe, indeed serene political environment for transient quests?

This leads to a final paradox: Why do so many developing nations make tourism development a priority industry when, more than any other, tourism is the most fragile, precarious, and vulnerable of industries to sustain?
That nations sometimes succeed in developing tourism well is perhaps more surprising than that they often fail. To understand both the attractions of tourism for developing nations and the challenges posed by it given these paradoxes, it is necessary to understand both the internal and external forces sometimes encouraging, sometimes constraining international tourism development.

\section{Why Develop Tourism?}

Tourism development is advocated and defended in developing nations primarily in economic terms. It is an export that raises foreign exchange without the extraction of raw materials or depletion of scarce resources. It provides employment in societies characterized by high unemployment or underemployment. It may even provide an economic or utility value to national treasures or to wildlife that the country could otherwise not afford to protect. Some kinds of tourism development also provide for an eoonomicdemand for traditional crafts and performances that would otherwise not be preserved as modernization takes place. Some types of tourism development $d o$ provide rail and road infrastructure, health clinics, and better mail, police, fire, sewer, and water resources that can benefit both tourist and citizen (Edgell, 1993).

Often unstated but at least as important in the minds of strategic elites are other political and economic factors. Political leaders since Franco of Spain (Pi-Sunyer, 1979: 46-69) have utilized tourism development selectively to showcase their regimes. Hitler did it with the 1936 Olympics. President Marcos (1969-1986) even went so far as to declare his martial law regime a tourist attraction, in that the government's despotic actions themselves created a place Where Asia Wears a Snile (Richter, 1980, 1982 and 1989).

It is, in general, a very shallow but satisfactory strategy in terms of impressing visitors and other creditor nations. Tour-
Mrs. Linda K. Fichter is professor of politica science at Kansas State Universty where she teaches public policy and public administration. 
ists are seldom curious about the civil liberties of those serving them provided order is maintained. Yet since they may harbor an illusion that, having seen the country, they are in a position to commenton its politics with some authority. Thus, they are useful for propaganda and promotional purposes. Often, authoritarian regimes are particularly good about maintaining order especially in the rather circumscribed areas frequented by tourists. Aveneer of progress can becreated by tourist infrastructure that often persuades creditors to lend more aid and to investmore than in countries without an active tourism industry.

Thus, though most of the world's tourism occurs in developed nations, a disproportionate stake in tourism may be created in very poor nations. Hence, thevulnerability of tourism to forces both from within and without. Even developed countries like the United States where tourism is the third largest industry, have seen regions devastated when crime and/or natural disasters have created negative publicity for the industry (Booth, 1994; Castle, 1989; Wichita Eagle, April 24, 1994; March 28, 1994; Molnar, 1989; 4T).

What makes tourism so uniquely vulnerable as an industry is the very essence of its promised product: a great vacation. No matter how that vacation is packaged from safaris to sandcastles, it implies freedom from worry, stress, an emphasis on discretionary pleasure. Moreover, the tourist typically is bombarded with scores of almost equally attractive travel destinations from which to choose. Any hint of insecurity or danger at one destination is likely to encourage selection of an alternative site. Actual conditions may be almostincidental compared with popular perceptions. Tourist fickleness, quest for variety at best challenge the industry. Also, most developing nations are distant from tourismgenerating nations. Violence, rebellion, natural disaster or petty crime can destroy their tourism image and bankrupt the industry.

In this article, six problems of political insecurity will be examined, any one of which can unglue the most sophisticated advertising plans. Though none of these is unique to developing nations, as will be demonstrated throughout, the impact of a fragile industry under seige coupled with the inadequate resources of a developing nation make tourism development a con- siderably more risky investment than its promoters will acknowledge.

\section{International Perceptions/National Warnings}

One of the most difficult problems for a developing nation to control is its international perception at any point in time. Faced with an IRA bombing in London or airport violence in Greece, tourism plummets but soon recovers in the face of the media blitz developed nations can muster (Brady and Widdows, 1988: 8-10; Conant, Clark, Burnett and Zank, 1988: 16-20; Richter and Waugh, 1986: 230-238). In April, 1994 the U.S. Secretary of Commerce personally delivered $\$ 3$ million to the Mayor of Los Angeles for tourism promotion to counter the images of riots, fires, and earthquakes (Los Angeles Times,April 8, 1994). Developing nations have no such resources and are only episodically reported in the Western press, usually at times of political upheaval or naturạl disasters.

Incidental press reports are one thing, but the political nature of tourist-generating government warnings pose even greater problems. For example, the Japanese government is famous for its travel warnings which are usually taken quite seriously by its outbound citizens (Wichita Eagle, March 29, 1994: 8A; O'Grady, 1990: 26). Many developing nations are heavily dependent on two or three countries for their tourists. When a heal thor security warning comes from the Japanese government, third world resorts become ghost towns; hotels deserted. The Philippines, on several occasions, has seen its important Japanese visitor market vanish almost overnight (Richter, 1982 and 1989).

At any given time, the U.S. has actual don't go warnings for two three dozen nations, of which over four-fifths are developing nations(Consumer Reports Travel Letter, each month; Edgell, 1990; Trick, 1989). An additional number of developing nations, like Cuba, North Korea, and Vietnam, may belegally off-limits to Americans for political reasons.

The U.S. Stage Department warnings are themselves based on less than objective criteria. Countries ideologically close to the United States apparently requirea much higher level of danger to U.S. citizens, e.g.
Israel, Brazil, Mexico, Egypt and South Africa than countries at political odds with the U.S. like Libya and Iran (Wichita Eagle, March 13, 1992; 4A). The Philippines was seldom included in warnings when the U.S. had Clark Air Force Base and Subic Bay Navel Base there. Now, with objectively far less civil unrest, the warnings about travel to the Philippines have been more or less continuous. Despite the civil unrest in Mexico, a political assassination and a history of crime against tourists - particularly those traveling by road - Mexico is not cited. A NAFTÁ dividend perhaps?

Even despite tourists being the targets of attacks by Islamic fundamentalists, Egypt, a major recipient of U.S. aid, has not been mentioned in State Department warnings (Consumer Reports TravelLetter, April, 1994: 74, 96). Nor does the United States ever include any internal locations in its warnings, despite the fact that U.S. violent crime is a major depressant in international travel to the U.S. (even a mid-size city like Wichita, Kansas has a homiciderate higher than Belfast, Northern Ireland!).

Developing nations, then, must be concerned not only with actual instability, but also perceived threats to visitor security and political relations with tourist-generating nations.

\section{Regional Turmoil}

Another perceptual factor largely outsidea developing nation's control is regional instability. Precisely because many developing nations are far from tourist-generating nations, many visitors plan multicountry tours. Regional political strife any cripple a tourist industry in a nation in which tourists may be quite secure. Pakistan and India, for example, are nations of incredibly diverse and rich touristic sites in which tourists are generally very well treated. Yet, their international tourism has been minuscule because of civil war in Sri Lanka, border disputes with China, chronic political and natural disasters in Bangladesh and hostility between India and Pakistan over Kashmir (Richter, 1989).

Pakistan's overland tourism was thwarted for nearly 15 years by the Iraq-Iran war, the Sovietinvasion of Afghanistan, and sporadic violence in Turkey (Richter, 1984: 9-13). 


\section{Internal Strife in Non-Tourist Areas}

Poor communication, inadequate media explanation and erratic reporting make it difficult for would-be tourists to differentiate from touristicareas like Machu Picchu in Peru which arevulnerable to the Shining Path guerrillas and sporadic violence in India, Mexico and Jamaica which are far from areas of touristic interest (Podesta, 1994: 18).

African tourism which represents only 2.6 percent of global tourism receipts has also been crippled by the scores of successful coups and ethnic violence (Teye, 1988: 487-503). Rwanda and Burundi are only the latest horror stories which will impact not only tourism to both countries, especially wildlife tourism, but travel to the whole continent. Tourists have difficulty discriminating between the very different security situations that prevail among nations that are all unfamiliar to the traveler. ThescourgeofAids has also been portrayed as more endemic to Africa and few tourists may be able to discern high risk and low risk destinations.

\section{Turmoil in Touristic Areas}

Sri Lanka, Cambodia, Fiji, Lebanon, Haiti, Peru, the Philippines and most recently the former Yugoslavia and Rwanda are countries that have had significant tourism investments or as in Rwanda's case half of the world's gorillas threatened by the civil strifethat has torn thenations apart(Richter, 1982; 1989; 1993). Interestingly, the greatest threat to nations in the 1980 s and 1990 s has not been external threat but internal factions and/or anarchy.

Political elites are often sufficiently enamored with the glamour and opportunity for lucrative private investments and imports associated with international tourism that they fail to assess the vulnerability of such tourism relative to the likelihood of internal violence.

$\mathrm{Also}$, in some nations like the former $\mathrm{Yu}$ goslavia the health and vitality of the tourist industry built on multicultural sites may have postponed the disintegration of the country after General Tito's death. Certainly few could have forecast in 1984 at the Winter Olympics in Sarajevo that the country would self destruct during thenext decade.
When violence, however sporaticor severe dampens tourist arrivals, for whatever reason, the problem is compounded by the luxury paradox. Five star hotels cannot be easily converted into office buildings or apartment houses (Goonatilake, 1978:15). Many are too remote, too energy dependent, too lavish for conversion to more basic facilities. Campgrounds or low rise modest facilities, on the other hand, can convert to clinics, schools, building sites.

\section{Tourism as the Target of Political Strife}

Tourism policy is a chasen policy. No nation is forced to develop a tourism plan (Hirschman: 385-402). Education, agriculture, and foreign policy are not optional and therefore get more attention and debate even in developing nations. Elites are freer to pursue tourism strategies because tourism generally has not established constituencies. Tourist infrastructure also provides dear evidence of modernization even if the contribution to genuine development is suspect.

In the past tourism seldom evoked protest until it had gone awry, but today groupsare more aware not only of its potential but also of its pitfalls. Particularly for fundamentalist religious groups tourism's secular pilgrimagecan be an anathema. Islamic fundamentalists have been active in Pakistan since the military coupin 1977 toppled Prime Minister Z. A. Bhutto, a tourism promoter. Folk dancing, liquor in hotels, unveiled women, have been targets of their protests (Richter, 1984 and 1989). More recently, Islamic fundamentalists have sought to destroy Egypt's number one industry by attacking tourists and making threats to the international media (Wichita Eagle, February 8, 1994: 8A).

While Islamic examples have been in the news, Christian and Buddhist groups have also protested what they see as a pernicious association between tourism and sexual exploitation of children, spread of AIDS, and displacement of traditional livelihoods (O'Grady, 1990: 22; Hall, 1993: 67-74). While their protests have not been violent, they have been quite effective at drawing attention to the downside of third world tourism.

In the Philippines, tourismalso became the target of anti-government protests in the period 1979-1986. There, the issue was less the genuine problems of sex tours and ecological issues associated with the government's tourism policy though they had their critics than the Marcos government's use of tourism. The really violent attacks - burning of luxury hotels, bombing of conventions, were aimed not at tourism per se, but at the Marcos dictatorship.

The Marcos family not only used the government insurance system to fund crash programs of five star hotel construction but were also owners of several hotels. Moreover, the excesses associated with Marco's attempt to use tourism for political favor abroad make tourism itself an attractive target for opposition groups without legal channels of dissent (Richter, 1980,1982 and 1989). Because foreigners were injured or threatened by the violence, the government was powerless to suppress news of the attacks. Tourism plummeted. Both sides have used tourism for political gain, but the scattered opposition demonstrated how much easier it is to destroy than to build, a lesson now being learnedin Egypt.

\section{Tourists as Targets of Crime}

A newer and still more terrifying source of fragility for tourism industries everywhere are the apolitical attacks on tourists. Travelers as tourists are both obvious and anonymous making them an ideal target for robbery, kidnapping, fraud. They have money on them and by their freedom to travel have access to potentially large sums that could be raised for ransoms. Kidnapping of Japanese tourists for ransoms was a seriousproblem in the Southern Philippines in the early 1980s. Tourists drive identifiable rental cars, have expensive cameras, are relaxed and careless with hotel keys and belongings, and are generally unsophistcated about sources of danger.

Thus, they are easy targets and their assailants are almostimpossible toapprehend. Even if suspects are caught, the ability to bribe police in developing nations makes arrests unlikely. Also, because tourists are not around by the time the accused are brought to trial makesconvictions unlikely.

Brazil, particularly Rio, the Philippines, and Kenya are only three of dozens of 
developing nations where tourism is depressed because of violence against tourists.

\section{The Dilemma}

Tourism does offer real opportunities and even a comparative advantage for certain attractions in many developing nations. But the very factors that make these nations less developed are the same circumstances that make tourism development a particularly risky industry.

Developing nations typically lack the disciplined troops, honest police, and high technology resources to combat crime in both tourist and non-tourist areas. They lack the promotional funds to counter even erroneous images ofinsecurity in the international media. Moreover, there is an inevitable conspicuous consumption gap between affluent tourists and the overall population. Political instability frequently spills over the often artificial legal boundaries of nations whose borders reflect colonial legacies rather than geopolitical or cultural demarcations. An inability to control border regions is also characteristic of developing nations.

Thus, even with enlightened, uncorrupt, democratic leadership - always in scarce supply in developed and developing nations - there are intrinsic obstacles to tourism success, let alone the more fundamental goal of utilizing tourism for development. As this author noted following a ten-nation study of tourism development:

Nor for all the rbetoric that surrounds tourism as an agent of peace and goodwill, ... (thisstudy) ... found no evidence at all that the prospects of tourism income contributed to political stability to a willingness to compromise, internally or within the region or that the tourism industry became less fragile over time. (Richter, 1993: 45)

Tourism is intrinsically a fragile industry in any country and especially so in developing nations. The vulnerability of the industry can be reduced, however, if planners will include a political audit in their planning. Inventorying wildlife, beaches, and historical sites says little about the success of a destination. By those factors Singapore should be a flop and neighboring Malaysia a stunning success. Developing a more modest, ecologically sustainable tourism product is also a way of making infrastructure in roads, trains, and buses serve citizens and domestic tourists. This also avoids creating isolated enclaves of affluence for international visitors that can become targetsat worstor unusable if tourismdeclines. Growing domestic tourism helps to decrease seasonality of attractions, promotes less resentment, and is characterized by fewer demands for imports.

Curbing the seamier elements of tourism, e.g. prostitution, pedophilia tours, may be difficult to do with underpaid police and the potential for kickbacks, but more wholesomedestinations are rewarded with longer periods of stay and fewer social problems, thereby making more conservative, low profile tourism a better investment.

Tourism is not going to disappear however much some groups may wish it were so. The challenge is for scarce development resources to be channeled in ways that benefit the stability of tourism growth by enhancing the opportunities for the host population.

\section{BIBLOGRAPHY}

Bandits, Have a Field Day Preying an Set-Up Tourists in Mali Desert, Wichita Eagle, May 1, 1992, 6A

BOOTH, William, Florida Turns Up the Hest on Cnme, Washington Post, February 21-27, 1994

BRADY, Jahn and Pichard WIDDOWS. The Impact of World Events on Travel to Europe During the Summer of 1986 , Journal of Travel Research. Winter 1988, 8-10.

Bus is Ambushed in City in Egvpt, Kansas Clty Star. November 13, 1992

Cariacking Deaths Horrify Japanese. Wichita Eagle, March 28, 1994, 3A.

CASTLE, Ken, How Global Politics infiuence our Vhca. tions. Travel-Holiday. February, 1989, 16.

CONANT, Jeffrey S., CLARK, Terry, BUANETT, John J. and Garl ZANK, Terrorism and Trawel: Managing the Unmanageable, Journal of Travel Research. Spring. 1968, 16-20.

Consumer Reports Travel Lotter, April, 1994, 74, 95 EDGELL, David, Sr, World Tourism at the Millenium, Washington, D.C., Department of Commerce, 1993.

EDGELL, David, Sr. Charting a Course for International Tourism in the $1990^{\prime} \mathrm{s}$, Washington, D.C. Department of Commerce, 1990.

Fareigners Warned Again to Leave Egypt, Whehlta Eagle, February B, 1904, BA.

Forget Acapulco: Libya Wants You, Wichita Eagle, March $13,1992,4 \mathrm{~A}$.

GOONATALIKAKE, S., Tourism in Sri Lanka, People's Bank, Colombo, 1978.

HALL, C, Michael, Sex Towism in Southeast Asia, in David Harrison, ed. Tourism and the Less Developed Countriea, London, Belhaven, 1993, 35-46.
HARAELL-BOND, Barbara, A Window on an Outside World: Touriamas Development in the Gambia, American University Field Staff Reports, no 19. 1978.

HIRSHMAN, Albert, Policy Making and Policy Analysis in Latin America, Polley Selences, 6, 385-402.

LAQUEUR, Walter, Reflections on Terrorism, Foraign Affairs, 65(1), Fall, 1986, 81-93.

Los Angeles Times, April 8, 1994.

MOLNAR, Jim, How Poltics and Fear influence Tourism, St. Louls Post Dlepatch, September 3, 1989, 4T.

Mondale Apologizes in Japan for Carjacking Deaths, Wichita Eagle, March 29, 1994, 8A

NAJAM, Adil, Tourist Trap. The Herald, February, 1992. 143.

O'GRADY, Ron, The Challenge of Touriam, Bangkok, ECTWT, 1990

PI-SUNYER, Oriol, The Politics of Tourism in Catalonis, Mediterranean Studies, I, no 2, 1979, 46-69.

PODESTA, Don, Peru's Resurgence of Tradition and Tourism, Washington Post, National Weekly Edition, January 10-16, 1994, 18.

RICHTER, Linda $K$, Land Reform and Tourism Do velopment: Policy-Making in the Philippines, Cambridge, MA, Schenkman, 1982.

RICHTER, Linda $K$., The Political Uses of Tourism; $A$ Philipoine Case Study, Journal of Developing Aroas, January, 1980, 237-267.

FICHTER, Linda $K_{\text {, }}$, The Potential and Pitfalls of Tourism Planning in Third World Nations: The Case of Pakistan, Tourism Recreation Research, 9(1). $1984,9-13$.

RICHTER, Linda K. The Politics of Tourism in Asia, Honolulu, University Press of Hawaii, 1989.

RICHTER, Linda K. Paitical Instability and Tourism in the Third Word, in Dawid Harrison, ed., Tourism and the Less Developed Countries, London. Belhaven, 1990, 35-46.

RICHTER, Linda K and WAUGH, William, Jr., Terrovism and Tourism as Logical Companions, Tourism Management, 7, 1986, 230-238.

TEYE, Victor B, Geographic Factors Affecting Towism in Zambia, Annals of Tourism Research, 15(4). $1986,487.500$.

The Economics, March 28, 1992. 120.

TRICK, Darcy Reid, Oppression: The Rise and Fall of Tourism, USA Today, November 14, 1989, 1.

WA.HNSCHAFFT, Ralph, Formal and hiormal Tourism Sectors: A Case Study in Pattava, Thailand, Annals of Tourism Research, 913). 1982,429-451.

Waming: Travel With Care, Time, April 21, 1996, 58-59. WOOD, Fobert E. The Econamics of Tourism, Southeast Asla Chronlcle, April, 1991, 2-13. 